\title{
PENGARUH TINGKAT PENDIDIKAN, MASA KERJA, PELATIHAN DAN JABATAN TERHADAP KUALITAS LAPORAN KEUANGAN PEMERINTAH KABUPATEN MINAHASA SELATAN
}

\author{
Jhon Fiesgrald Wungow \\ Linda Lambey \\ Winston Pontoh
}

(Email : isakwungow@gmail.com)

\begin{abstract}
This study is aimed to examine the effect of educational level, working period, training and government officers of the quality of government financial reports South Minahasa regency simultaneously and partially. The population was taken employees who work as treasurers and chiefs financial sub-section of the local work units and in accounting and treasury areas in the Office of Financial Management, Revenue and Asset South Minahasa regency.

The research sample was 100 respondents and only 95 respondents who participated by answering questionnaires. The variables in this study are independent variable consist of level of education $\left(X_{1}\right)$, working period $\left(X_{2}\right)$, training $\left(X_{3}\right)$ and government officers $\left(X_{4}\right)$ on the other hand, dependent variable is the quality of local financial statement $(Y)$. Data were analyzed using multiple linear regression analysis (multiple regression).

The results showed that the level of education, working period, training and official simultaneously have a significant impact on the quality of local financial statement. The value of the coefficient of determination shows that the level of education, working period, training and government officers together contribute to the quality of local financial statements in the amount of 40.1\%, while the remaining of 59.9\% is influenced by other factors beyond the research model. Partial test results showed that only training and government officers have an impact on the quality of local financial statement. The level of education and working period do not have any influence on the quality of government financial reports South Minahasa regency.
\end{abstract}

Keywords: quality of local financial statement, level of education, working period, training, government officers.

\section{PENDAHULUAN}

Otonomi daerah merupakan hak, wewenang, dan kewajiban daerah otonom untuk mengatur dan mengurus sendiri urusan pemerintah dan kepentingan masyarakat setempat sesuai dengan peraturan perundang-undangan. Hal tersebut sesuai dengan ketentuan umum Undang-Undang Nomor 32 tahun 2004 tentang Pemerintahan Daerah. Kebijakan pemerintah Indonesia tentang Otonomi Daerah, merupakan kebijakan yang dipandang sangat demokratis dan memenuhi aspek desentralisasi yang sesungguhnya. Peraturan Pemerintah Nomor 7 Tahun 2008 tentang dekonsentrasi dan tugas pembantuan, melimpahkan sebagian kewenangan Pemerintah Indonesia kepada Gubernur selaku wakil pemerintah pusat di daerah untuk menyelenggarakan tugas dekonsentrasi melalui pelimpahan sebagian urusan pemerintahan yang menjadi kewenangan kementerian dan lembaga.

Peraturan Menteri Dalam Negeri (Permendagri) nomor 59 Tahun 2007 menyebutkan, bahwa untuk tujuan akuntabilitas atas pengelolaan dana-dana yang dikelola oleh provinsi atau kabupaten/kota diwajibkan menyiapkan laporan keuangan pemerintah daerah. Salah satu indikator utama yang menunjukkan keberhasilan pemerintah dalam mempertanggungjawabkan pengelolaan anggarannya adalah dengan terwujudnya laporan keuangan yang berkualitas. 
Laporan keuangan yang berkualitas merupakan laporan yang dapat menyajikan informasi yang benar, jujur, relevan, andal, dapat diperbandingkan, dan dapat dipahami. Laporan keuangan yang berkualitas penting karena akan dipakai sebagai dasar dalam pengambilan keputusan. Selain itu informasi laporan keuangan yang berkualitas akan mengikis kekurangpercayaan masyarakat terhadap pemerintah daerah dengan adanya berbagai skandal keuangan yang terjadi.

Laporan keuangan yang tidak berkualitas (buruk) memberikan peluang bagi adanya penyimpangan dan kekeliruan di bidang keuangan. Hal tersebut akan menimbulkan kecurangan, korupsi, kolusi yang bisa menimbulkan tuntutan hukum. Jika berlangsung terus menerus tentu saja rakyat akan menanggung akibatnya, biaya transaksi yang tinggi dan pelayanan kepada publik yang buruk. Selanjutnya, berakibat pada terjadinya krisis kepercayaan baik masyarakat, kreditur, dan investor internasional akan ragu menempatkan dananya di Indonesia, kecuali dengan beban yang tinggi.

Secara umum kualitas Laporan Keuangan Pemerintah Daerah (LKPD) masih buruk dapat dilihat dari hasil pemeriksaan BPK terhadap 504 LKPD dan hanya $251(49,80 \%)$ yang diberikan opini WTP oleh BPK sedangkan opini WDP atas 230 (45,64\%) LKPD, TW atas 4 (0,79\%) LKPD, dan opini TMP atas 19 (3,77\%) LKPD (IHPS I Tahun 2015, BPK). Capaian LKPD ini dibawah target RPJMN 2010-2014 yang menetapkan opini WTP atas seluruh LKPD pada Tahun 2014. Padahal pemerintah telah melakukan reformasi manajemen keuangan negara/daerah untuk menghasilkan laporan keuangan berkualitas sesuai dengan kriteria tersebut di atas. Reformasi tersebut dilakukan melalui peningkatan kualitas sumber daya manusia (SDM) dan peraturan perundang-undangan yang menggunakan anggaran yang tidak sedikit baik melalui anggaran pemerintah daerah maupun pemerintah pusat.

Opini BPK RI untuk Pemda SULUT lima tahun terakhir, kualitas LKPD di wilayah Provinsi Sulawesi Utara masih mengecewakan. Masih banyak LKPD kabupaten/kota yang mendapat opini TMP dari hasil pemeriksaan BPK lima tahun terakhir tidak terkecuali Kabupaten Minahasa Selatan. Pemerintah Kabupaten Minahasa Selatan belum pernah mendapatkan opini Wajar Tanpa Pengecualian (WTP) dari BPK, pada tahun 2010 mendapatkan opini Tidak Memberikan Pendapat (Disclaimer), tahun 2011 mendapatkan opini Tidak Memberikan Pendapat (Disclaimer), tahun 2012 kembali mendapatkan Tidak Memberikan Pendapat (Disclaimer), tahun 2013 mendapatkan opini Tidak Wajar (Adverse) dan tahun 2014 mendapat opini Wajar Dengan Pengecualian (WDP).

Fenomena buruknya kualitas laporan keuangan pemerintah daerah menuntut setiap pengelola keuangan harus memiliki pengetahuan yang baik mengenai laporan keuangan sehingga laporan yang dipublikasikan dapat disajikan secara wajar terbebas dari salah saji yang material sehingga tidak menyesatkan pembaca dan pengguna laporan. Tanpa pengetahuan laporan keuangan yang baik mengakibatkan laporan keuangan yang dipublikasikan terdapat kesalahan material dalam penyajian angka, tidak sesuai dengan pelaporan dan tidak tepat waktu dalam penyampaiannya sehingga berdampak buruk bagi pengguna laporan dan pihak penyaji laporan itu sendiri.

Sejalan dengan bergulirnya reformasi, peran pemerintah daerah adalah memberikan pelayanan publik secara efektif dan efisien. Hal ini tentu menuntut pemerintah daerah dalam pengelolaan, pengaturan keuangan dan anggaran daerah secara ekonomis, efisien, efektif, transparan dan akuntabel. Peran tersebut menuntut sumber daya manusia yang berkualitas. Salah satu indikator sumber daya manusia berkualitas adalah tingkat pendidikan. Sumber daya manusia yang berkualitas dengan pendidikan yang tinggi akan mampu membantu aparatur dalam menyelesaikan tugas terutama dalam penyusunan anggaran dan laporan keuangan daerah.

Kualitas sumber daya manusia juga ditentukan oleh masa kerja, karena dengan masa kerja yang lebih lama, karyawan tentunya telah berpengalaman dalam menghadapi dan menyelesaikan masalah-masalah pemerintahan khususnya dalam penyusunan anggaran dan laporan keuangan. Sandra (1999) dikutip Yudhi dan Meifida (2006) menyatakan bahwa efek dilusi dalam auditing bisa berkurang oleh auditor yang berpengalaman menyebabkan mereka mengabaikan informasi yang tidak relevan. Dengan kata lain, kompleksitas tugas yang dihadapi sebelumnya oleh seseorang akan menambah pengalaman serta pengetahuannya. 
Hal lain yang tidak kalah penting adalah pelatihan, mengingat bahwa melalui pelatihan mampu memberikan tambahan kemampuan dalam menghadapi perubahan maupun penyesuaian sistem kerja di masa mendatang. Boner dan Walker (1994) dikutip oleh Yudhi dan Meifida (2006), mengatakan bahwa peningkatan pengetahuan yang muncul dari pelatihan formal sama bagusnya dengan yang didapat dari pengalaman khusus. Pengalaman tersebut berupa kegiatan-kegiatan seperti seminar, simposium, lokakarya pelatihan itu sendiri dan kegiatan penunjang keterampilan lainnya.

Hasil penelitian yang ditemukan oleh Zetra (2008) mengungkapkan bahwa pemahaman sebagian pejabat penatausahaan keuangan SKPD terhadap mekanisme pengelolaan keuangan masih sangat kurang. Misalnya banyak bendahara penerimaan pada SKPD yang terlambat menyampaikan pertanggungjawaban disebabkan antara lain pengguna anggaran belum tanda tangan. Selain itu, pimpinan kegiatan atau pimpinan SKPD beranggapan bahwa urusan pertanggungjawaban hanyalah tanggung jawab bendahara saja.

\subsection{Landasan Teori \\ Tingkat Pendidikan}

Undang-Undang Republik Indonesia pasal 1 Nomor 20 Tahun 2003 tentang Pendidikan Nasional, pengertian pendidikan adalah usaha sadar dan terencana untuk mewujudkan suasana belajar dan proses pembelajaran agar peserta didik secara aktif mengembangkan potensi dirinya untuk memiliki kekuatan spiritual keagamaan, pengendalian diri, kepribadian, kecerdasan, akhlak mulia, serta keterampilan yang diperlukan dirinya, masyarakat, bangsa dan negara. Pendidikan sering diartikan sebagai usaha manusia untuk membina kepribadiannya sesuai dengan nilai-nilai di dalam masyarakat dan kebudayaan. Selanjutnya, pendidikan diartikan sebagai usaha yang dijalankan oleh sesorang atau kelompok orang lain agar menjadi dewasa atau mencapai tingkat hidup atau penghidupan yang lebih tinggi dalam arti mental (Hasbullah, 2008).

Menurut Undang-undang Republik Indonesia Nomor 20 Tahun 2003 Tentang Sistem Pendidikan Nasional, tingkat pendidikan atau sering disebut dengan jenjang pendidikan adalah tahapan pendidikan yang ditetapkan berdasarkan tingkat perkembangan peserta didik, tujuan yang akan dicapai dan kemampuan yang dikembangkan.Jenjang pendidikan formal terdiri dari pendidikan dasar, pendidikan menengah dan pendidikan tinggi.

1. Pendidikan Dasar

Pendidikan dasar adalah pendidikan umum yang lamanya sembilan tahun, diselenggarakan selama enam tahun di sekolah dasar dan tiga tahun di sekolah lanjutan tingkat pertama atau satuan pendidikan yang sederajat.Pendidikan dasar merupakan jenjang pendidikan yang melandasi jenjang pendidikan menengah. Pendidikan dasar berbentuk Sekolah Dasar (SD) dan Madrasah Ibtidaiyah (MI) atau bentuk lain yang sederajat serta Sekolah Menengah Pertama (SMP) dan Madrasah Tsanawiyah (MTs.) atau bentuk lain yang sederajat.

2. Pendidikan Menengah

Pendidikan menengah adalah pendidikan yang diselenggarakan bagi lulusan pendidikan dasar yang mengutamakan perluasan dan peningkatan ketrampilan siswa.Pengembangan pendidikan menengah sebagai lanjutan pendidikan dasar di sekolah ditingkatkan agar mampu membentuk pribadi manusia yangberiman dan bertakwa terhadap Tuhan Yang Maha Esa dan berbudi pekerti luhur serta untuk memenuhi kebutuhan pembangunan yang memerlukan tenaga berkemampuan dan berketerampilan. Perlu diadakan penyesuaian kurikulum dan isi pendidikannya serta penataan kelembagaan pendidikan menengah, termasuk pendidikan kejuruan yang merupakan pembekalan untuk pendidikan tinggi atau bekal hidup dalam masyarakat.

3. Pendidikan Tinggi

Pendidikan tinggi merupakan jenjang pendidikan setelah pendidikan menengah yang mencakup program pendidikan diploma, sarjana, Magister, Spesialis dan Doktor yang diselenggarakan 
oleh Perguruan Tinggi.Perguruan tinggi di sini dapat berbentuk akademi, politeknik, sekolah tinggi, institut atau universitas, pendidikan tinggi diselenggarakan dengan sistem terbuka. 


\section{Masa Kerja}

Menurut Nitisemito (1996) menyatakan bahwa senioritas atau sering disebut dengan istilah "Length of service" atau masa kerja adalah seorang karyawan menyumbangkan tenaganya pada perusahaan tertentu. Sejauh mana tenaga kerja dapat mencapai hasil yang memuaskan dalam bekerja tergantung dari kemampuan, kecakapan, dan keterampilan tertentu agar dapat melaksanakan pekerjaannya dengan baik.

Nawawi (1981: 21) menjelaskan bahwa pengalaman masa lalu akan sangat berguna dalam mendukung pengetahuan yang dimiliki bilamana seseorang menghadapi masalah-masalah baru. Tidak jarang ditemukan adanya beberapa orang yang belum melaksanakan tugasnya dengan baik, secara psikologis mereka belum matang dalam menjalankan tugas yang baru, dan mereka memerlukan waktu tertentu bahkan cukup lama dalam memahami pekerjaan dan seluk beluk organisasinya. Surachmad (1982: 26) mendefinisikan pengalaman adalah pelajaran yang akan menghasilkan perubahan ke arah kematangan tingkah laku, pertambahan pengertian serta pengajaran informasi.

Fuller (1969: 13) menyatakan bahwa seorang yang ahli dalam memperbaiki dan meningkatkan proses belajar mengajar dituntut memiliki pengetahuan dan keterampilan dalam proses belajar mengajar serta memiliki ijazah sesuai dengan tugasnya. Dengan demikian masa kerja guru dalam menjalankan tugasnya dapat dihitung semenjak guru tersebut setelah memiliki ijazah formal perguruan tinggi dan telah memiliki ikatan dengan lembaga pendidikan, sekolah atau madrasah dimana dia memperoleh pengetahuan dan keterampilan mengajarnya.

\section{Pelatihan}

Sumantri (2000:2) mengartikan pelatihan sebagai proses pendidikan jangka pendek yang menggunakan cara dan prosedur yang sistematis dan terorganisir. Para peserta pelatihan akan mempelajari pengetahuan dan keterampilan yang sifatnya praktis untuk tujuan tertentu. Sedangkan Moekijat (1991:2) menjelaskan istilah latihan untuk menunjukkan setiap proses untuk mengembangkan bakat, keterampilan dan kemampuan pegawai guna menyelesaikan pekerjaan-pekerjaan tertentu.

Nitisetimo (1996:86) menyatakan bahwa pemberian pelatihan ditujukan agar para karyawan dapat menguasai pekerjaan yang menjadi tanggung jawabnya sehingga terwujudlah efisiensi dan efektifitas dalam pelaksanaan tugasnya. Sedangkan Hariandja (2007:169) menjelaskan pelatihan lebih ditekankan pada peningkatan kemampuan untuk melakukan pekerjaan yang spesifik pada saat ini. Terdapat beberapa alasan mengapa pelatihan harus dilakukan atau menjadi bagian yang sangat penting dari kegiatan manajemen sumber daya manusia, diantaranya: pegawai yang belum memahami secara benar bagaimana melakukan pekerjaan, adanya perubahan lingkungan kerja dan tenaga kerja, meningkatnya daya saing dan penyesuaian terhadap peraturan-peraturan yang ada.

\section{Jabatan}

Tulus (1996) mendefinisikan jabatan ialah pekerjaan yang telah melembaga dalam suatu instansi, perusahaan atau telah membudaya dalam masyarakat. Jabatan juga menyangkut tanggung jawab dan wewenang. Tanggung jawab ialah hal yang menjadi keharusan pemegang jabatan sedangkan wewenang ialah hak pemegang jabatan untuk menerima, menuntut kepatuhan, mengajukan pendapat, pengambilan keputusan akhir dan memerintahkan pelaksanaannya mengenai suatu hal tertentu.

Pujangkoro (2004) mendefinisikan jabatan ialah sekumpulan pekerjaan yang berisi tugastugas yang sama atau berhubungan satu dengan yang lain, dan yang pelaksanaannya meminta kecakapan, pengetahuan, keterampilan dan kemampuan yang juga sama meskipun tersebar di berbagai tempat. 


\section{Laporan Keuangan Pemerintah Daerah}

Menurut PP No. 71 Tahun 2010, laporan keuangan disusun untuk menyediakan informasi yang relevan mengenai posisi keuangan dan seluruh transaksi yang dilakukan oleh suatu entitas pelaporan selama satu periode pelaporan. Laporan keuangan terutama digunakan untuk mengetahui nilai sumber daya ekonomi yang dimanfaatkan untuk melaksanakan kegiatan operasional pemerintahan, menilai kondisi keuangan, mengevaluasi efektifitas dan efisiensi suatu entitas pelaporan, dan membantu menentukan ketaatannya terhadap peraturan perundang-undangan.

Mahmudi (2010:64) menyatakan bahwa banyak pihak yang menjadi pemangku kepentingan pemerintah daerah bukan orang yang berlatar belakang pendidikan akuntansi, padahal mereka berkepentingan terhadap laporan keuangan pemerintah. Untuk bisa memahami laporan keuangan secara komprehensif, perlu diketahui proses pelaporan, logika akuntansi dan memahami elemen laporan keuangan.

\section{Tujuan Pelaporan Keuangan Pemerintah Daerah}

Mahmudi (2010:4-5) menjelaskan secara garis besar tujuan penyajian laporan keuangan bagi pemerintah daerah adalah sebagai berikut.

1. Untuk memberikan informasi yang bermanfaat dalam pembuatan keputusan ekonomi, sosial dan politik.

2. Untuk alat akuntabilitas publik.

3. Untuk memberikan informasi yang digunakan dalam mengevaluasi kinerja manajerial dan organisasi.

Tujuan pelaporan keuangan dalam kerangka Konseptual Akuntansi Pemerintahan adalah untuk menyajikan informasi yang bermanfaat bagi para pengguna dalam menilai akuntabilitas dan membuat keputusan baik keputusan ekonomi, sosial maupun politik dengan:

1. menyediakan informasi mengenai kecukupan penerimaan periode berjalan untuk membiayai seluruh pengeluaran;

2. menyediakan informasi mengenai kesesuaian cara memperoleh sumber daya ekonomi dan alokasinya dengan anggaran yang ditetapkan dan peraturan perundang-undangan;

3. menyediakan informasi mengenai jumlah sumber daya ekonomi yang digunakan dalam kegiatan entitas pelaporan serta hasil-hasil yang telah dicapai;

4. menyediakan informasi mengenai bagaimana entitas pelaporan mendanai seluruh kegiatannya dan mencukupi kebutuhan kasnya;

5. menyediakan informasi mengenai posisi keuangan dan kondisi entitas pelaporan berkaitan dengan sumber-sumber penerimaannya, baik jangka pendek maupun jangka panjang, termasuk yang berasal daripungutan pajak dan pinjaman; dan

6. menyediakan informasi mengenai perubahan posisi keuangan entitas pelaporan, apakah mengalami kenaikan atau penurunan, sebagai akibat kegiatan yang dilakukan selama periode pelaporan.

\section{Karakteristik Kualitatif Laporan Keuangan Pemerintah Daerah}

PP No.71 Tahun 2010 tentang Sistem Akuntansi Pemerintah menyatakan karakteristik kualitatif yang dimiliki oleh Laporan Keuangan, yakni ukuran-ukuran normatif yang perlu diwujudkan dalam Informasi Akuntansi sehingga dapat memenuhi tujuannya. Keempat karakteristik berikut ini merupakan prasyarat normatifyang diperlukan agar Laporan Keuangan Pemerintah dapat dikatakan berkualitas, yaitu sebagai berikut.

1. Relevan, apabila informasi yang termuat didalamnya dapat mempengaruhi keputusan pengguna dengan membantu mereka mengevaluasi peristiwa masa lalu atau masa kini, dan memprediksi masa depan serta menegaskan atau mengkoreksi hasil evaluasi dimasa lalu. Informasi Laporan Keuangan yang relevan, yaitu :

a. memiliki manfaat umpan balik, yaitu informasi memungkinkan pengguna untuk menegaskan atau mengkoreksi ekspektasi mereka di masa lalu; 
b. memiliki manfaat prediktif, yaitu informasi dapat membantu pengguna untuk memprediksi masa yang akan datang berdasarkan hasil dasa lalu dan kejadian masa kini;

c. tepat waktu, yaitu informasi disajikan tepat waktu sehingga dapat berpengaruh dan berguna dalam pengambilan keputusan; dan

d. lengkap, yaitu informasi yang disajikan selengkap mungkin, mencakup semua informasi akuntansi yang dapat mempengaruhi pengambilan keputusan dengan memperhatikan kendala yang ada.

2. Andal, jika informasi dalam laporan keuanagn bebas dari pengertian menyesatkan dan kesalahan material, menyajikan setiap fakta secara jujur, serta dapat diverifikasi. Informasi yang andal memenuhi karakteristik :

a. penyajian jujur, yaitu informasi menggambarkan dengan jujur transaksi dan peristiwa lainnya yang seharusnya disajikan atau yang secara wajar dapat diharapkan untuk disajikan;

b. dapat diverifikasi, yaitu informasi yang disajikan dalam laporan keuangan dapat diuji, dan apabila pengujian dilakukan lebih dari satu kali oleh pihak yang berbeda, hasilnya tetap menunjukan simpulan dan tidak berbeda jauh; dan

c. netralitas, Informasi diarahkan pada kebutuhan umum dan tidak berpihak pada kebutuhan pihak tertentu.

3. Dapat dibandingkan, jika informasi yang disajikan dapat dibandingkan dengan laporan keuangan periode sebelumnya atau laporan keuanagn entitas pelaporan lain pada umumnya.

a. Perbandingan secara intenal dapat dilakukan bila entitas menerapkan kebijakan akuntansi yang sama dalam 1 tahun.

b. Perbandingan secara eksternal dapat dilakukan bila entitas yang dibandingkan menerapkan kebijakan akuntansi yang sama (antar entitas).

4. Dapat dipahami, jika informasi yang disajikan dapat dimengerti oleh pengguna dan dinyatakan dalam bentuk serta istilah yang disesuaikan dengan batas pemahaman para pengguna.

\section{KERANGKA KONSEPTUAL}

\section{Kerangka Konseptual Penelitian}

Kerangka pikir dari penelitian "Pengaruh Tingkat Pendidikan, Masa Kerja, Pelatihan dan Jabatan terhadap Kualitas Laporan Keuangan Pemerintah Kabupaten Minahasa Selatan” adalah sebagai berikut:

1. Jika pengelola keuangan memiliki tingkat pendidikan yang tinggi, maka kualitas laporan keuangan akan berkualitas.

2. Jika pengelola keuangan memiliki masa kerja yang tinggi, maka kualitas laporan keuangan akan berkualitas.

3. Jika pengelola keuangan banyak mengikuti pelatihan, maka kualitas laporan keuangan akan berkualitas.

4. Jika pengelola keuangan menerapkan tugas pokok dan fungsi jabatan dengan baik, maka kualitas laporan keuangan akan berkualitas.

Gambar berikut ini menjelaskan kerangka konseptual dari penelitian ini. 
"PENGARUH TNGKAT PENDIDIKAN, MASA KERJA, PELATIHAN

DAN JABATAN TERHADAP KUALITAS LAPORAN KEUANGAN PEMERINTAH KABUPATEN MINAHASA SELATAN"

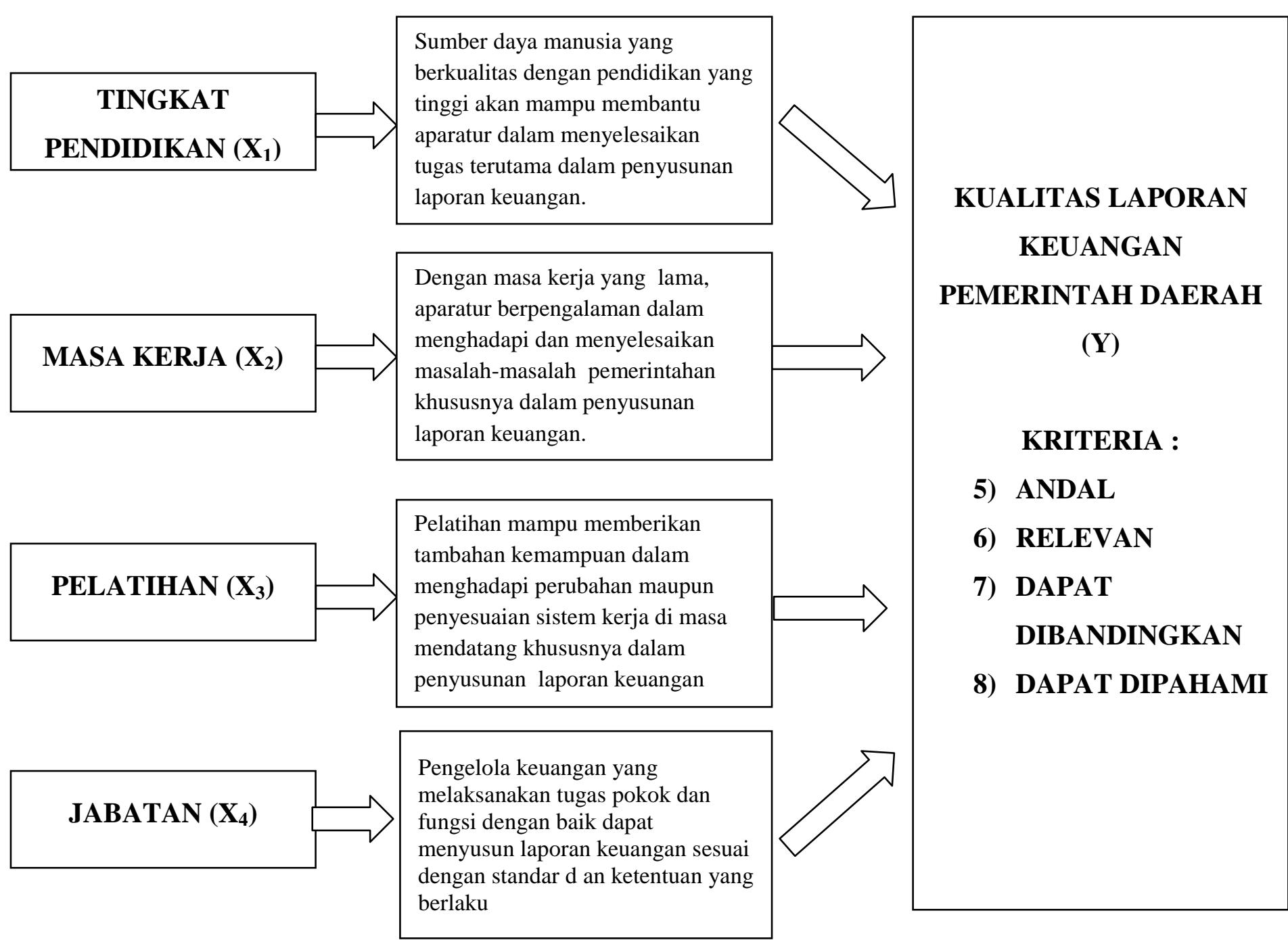

\section{Hipotesis Penelitian}

Berdasarkan tinjauan terhadap teori yang ada dan hasil penelitian sebelumnya, maka hipotesis penelitian ini adalah:

H1 : Diduga Tingkat Pendidikan berpengaruh terhadap Kualitas Laporan Keuangan Pemerintah Daerah.

H2 : Diduga Masa Kerja berpengaruh terhadap Kualitas Laporan Keuangan Pemerintah Daerah.

H3 : Diduga Pelatihan berpengaruh terhadap Kualitas Laporan Keuangan Pemerintah Daerah.

H4 : Diduga Jabatan berpengaruh terhadap Kualitas Laporan Keuangan Pemerintah Daerah. 


\section{METODE PENELITIAN}

\section{Jenis Penelitian}

Jenis penelitian yang akan digunakan untuk menganalisis Pengaruh Tingkat Pendidikan, Masa Kerja, Pelatihan dan Jabatan terhadap Kualitas Laporan Keuangan Pemerintah Kabupaten Minahasa Selatan adalah metode kuantitatif. Berdasarkan hubungan antara variabel yang diteliti, maka penelitian ini merupakan penelitian asosiatif kausal yaitu hubungan yang bersifat sebabakibat. Jadi penelitian ini akan menganalisis pengaruh variabel independen yaitu tingkat pendidikan $\left(\mathrm{X}_{1}\right)$, masa kerja $\left(\mathrm{X}_{2}\right)$, pelatihan $\left(\mathrm{X}_{3}\right)$ dan jabatan $\left(\mathrm{X}_{4}\right)$ terhadap variabel dependen yaitu kualitas laporan keuangan pemerintah daerah $(\mathrm{Y})$.

\section{Populasi, Sampel, dan Teknik Pengambilan Sampel}

Menurut Indriantoro (2002), populasi merupakan sekelompok orang, kejadian atau segala sesuatu yang mempunyai karakteristik tertentu. Populasi dalam penelitian ini adalah Satuan Kerja Perangkat Daerah (SKPD) yang berada di Pemerintah Kabupaten Minahasa Selatan antara lain : Inspektorat, Sekretariat Daerah, Sekretariat Dewan, Dinas, Badan, Kantor, Satuan dan Kecamatan dengan jumlah populasi sebanyak 51 SKPD.

Penyampelan atas responden pada penelitian ini dilakukan dengan teknik purposive sampling. Purposive sampling digunakan karena informasi yang akan diambil berasal dari sumber yang sengaja dipilih berdasarkan kriteria yang telah ditetapkan (Sekaran, 2006). Kriteria yang ditetapkan peneliti antara lain sebagai berikut :

1. Pegawai Negeri Sipil di SKPD Pemerintah Kabupaten Minahasa Selatan

2. Pegawai yang melakukan tugas dan fungsi pengelolaan dan pelaporan keuangan (bidang akuntansi dan perbendaharaan) pada Dinas Pengelola Keuangan, Pendapatan dan Aset Daerah di Pemerintah Kabupaten Minahasa Selatan.

3. Pegawai yang bekerja sebagai Kepala Sub Bagian Keuangan dan Bendahara Pengeluaran di setiap SKPD Pemerintah Kabupaten Minahasa Selatan.

\section{Lokasi dan Waktu Penelitian}

Lokasi penelitian ini dilakukan di Pemerintah Kabupaten Minahasa Selatan dengan sasaran Satuan Kerja Perangkat Daerah (SKPD) yang terdiri dari Dinas-Dinas, Badan-Badan, Kantor, Satuan dan Kecamatan-Kecamatan yang ada di Pemerintah Kabupaten Minahasa Selatan. Waktu penelitian selama 2 (dua) bulan yaitu mulai bulan Juni sampai dengan Juli 2016.

\section{Definisi Operasional dan Pengukuran Variabel}

1. Tingkat Pendidikan $\left(\mathrm{X}_{1}\right)$

Pendidikan adalah usaha sadar untuk menyiapkan peserta didik melalui kegiatan bimbingan, pengajaran dan latihan-latihan bagi peranannya dimasa yang akan datang. Indikator atau elemen data yang digunakan dalam tingkat pendidikan adalah pendidikan formal. Alat ukur yang digunakan dalam pengukuran variabel tingkat pendidikan menggunakan skala Likert.

2. Masa Kerja $\left(\mathrm{X}_{2}\right)$

Masa Kerja adalah lamanya seorang karyawan menyumbangkan tenaganya pada perusahaan tertentu. Indikator atau elemen data yang digunakan dalam masa kerja adalah lamanya bekerja di bagian keuangan. Alat ukur yang digunakan dalam pengukuran variabel masa kerja menggunakan skala Likert.

3. Pelatihan $\left(\mathrm{X}_{3}\right)$

Pelatihan lebih ditekankan pada peningkatan kemampuan untuk melakukan pekerjaan yang spesifik. Indikator atau elemen data yang digunakan dalam pelatihan adalah pelatihan yang diikuti. Alat ukur yang digunakan dalam pengukuran variabel pelatihan menggunakan skala Likert. 
4. Jabatan $\left(\mathrm{X}_{4}\right)$

Jabatan adalah kedudukan yang menunjukkan tugas, tanggung jawab, wewenang dan hak seseorang karyawan dalam rangka susunan satuan organisasi. Indikator yang digunakan dalam jabatan adalah tupoksi jabatan. Alat ukur yang digunakan dalam pengukuran variabel jabatan menggunakan skala Likert.

5. Kualitas Laporan Keuangan Pemerintah Daerah (Y)

Indikator atau elemen data dan alat ukur yang digunakan dalam mengukur kualitas laporan keuangan adalah relevan, andal, dapat dibandingkan, dan dapat dipahami dimana variabel ini didasarkan pada karakteristik kualitatif laporan keuangan Pemerintah (PP No. 71 Tahun 2010) yang kemudian diukur denganmenggunakan skala Likert.

\section{Pengujian Hipotesis}

Metode analisis yang digunakan untuk menguji hipotesis adalah metode regresi berganda (multiple regression) dengan persamaan regresi sebagai berikut:

$$
\mathbf{Y}=\mathbf{a}+\boldsymbol{\beta}_{1} \mathbf{X}_{1}+\boldsymbol{\beta}_{2} \mathbf{X}_{2}+\boldsymbol{\beta}_{3} \mathbf{X}_{3}+\boldsymbol{\beta}_{4} \mathbf{X}_{4}+e
$$

dimana,

Y $\quad$ : Kualitas Laporan Keuangan Pemerintah Daerah

a $\quad$ : Nilai intersep (konstanta)

$\beta 1, \beta 2, \beta 3, \beta 4$ : koefisien regresi

$\mathrm{X} 1 \quad$ : tingkat pendidikan

X2 : masa kerja

X3 : pelatihan

X4 : jabatan

e :error

\section{ANALISIS DAN PEMBAHASAN HASIL PENELITIAN}

\section{Deskriptif Data}

Pada saat pelaksanaan penelitian, kuesioner dibagikan kepada 100 responden dan hanya 95 responden yang mengembalikan kuesioner, yaitu 38 orang laki-laki dan 57 orang perempuan. Berdasarkan usia, sebanyak 14 responden $(14,74 \%)$ usia 20 - 29 tahun, sebanyak 55 responden $(57,90 \%)$ usia $30-39$ tahun, sebanyak 20 responden $(21,05 \%)$ usia $40-49$ tahun, sebanyak 6 responden $(6,32 \%)$ usia $50-58$ tahun. Berdasarkan status kawin, sebanyak 80 responden $(84,21$ $\%)$ sudah kawin, sebanyak 15 responden $(15,79 \%)$ belum kawin. Berdasarkan pendidikan, sebanyak 16 responden $(16,84 \%)$ dengan tingkat pendidikan SMA / SMK / Sederajat, sebanyak 72 responden $(75,79 \%)$ dengan tingkat pendidikan $\mathrm{S} 1$, sebanyak 7 responden $(7,37 \%)$ dengan tingkat pendidikan S2 dan sebanyak $0(0 \%)$ responden tingkat pendidikan S3. Berdasarkan masa kerja, sebanyak 0 responden $(0 \%)$ masa kerja $<1$ tahun, sebanyak 62 responden $(65,26 \%)$ masa kerja antara 1 tahun -10 tahun, sebanyak 26 responden $(27,37 \%)$ masa kerja antara 10 tahun -20 tahun, dan sebanyak 7 responden $(7,37 \%)$ masa kerja $>20$ tahun.

\section{Hasil Analisis Regresi}

$$
Y=6.817+0.016 X_{1}-0.084 X_{2}+0.508 X_{3}+0.310 X_{4}+e
$$

Persamaan regresi berganda di atas dapat dijelaskan sebagai berikut:

1. Tingkat pendidikan memiliki pengaruh positif terhadap kualitas laporan keuangan pemerintah daerah dengan nilai koefisien regresi sebesar 0,016 sehingga penambahan satu satuan tingkat pendidikan akan menambah kualitas laporan keuangan sebesar 0,016 satuan.

2. Masa kerja memiliki pengaruh terbalik (negatif) terhadap kualitas laporan keuangan pemerintah daerah dengan nilai koefisien regresi sebesar -0,084 sehingga penurunan satu satuan masa kerja akan menambah kualitas laporan keuangan sebesar 0,084 atau sebaliknya. 
3. Pelatihan memiliki pengaruh positif terhadap kualitas laporan keuangan pemerintah daerah dengan nilai koefisien regresi sebesar 0,508 sehingga penambahan satu satuan pelatihan akan menambah kualitas laporan keuangan sebesar 0,016 satuan.

4. Jabatan memiliki pengaruh positif terhadap kualitas laporan keuangan pemerintah daerah dengan nilai koefisien regresi sebesar 0,310 sehingga penambahan satu satuan jabatan akan menambah kualitas laporan keuangan sebesar 0,310 satuan.

\section{Pengujian Hipotesis Secara Simultan (Uji F)}

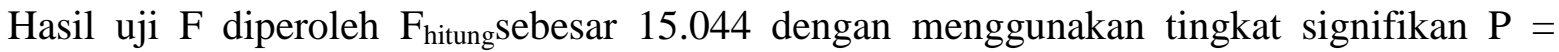
$0.000<\alpha=0.05$ maka dapat disimpulkan bahwa variabel Tingkat Pendidikan $\left(\mathrm{X}_{1}\right)$, Masa Kerja $\left(\mathrm{X}_{2}\right)$, Pelatihan $\left(\mathrm{X}_{3}\right)$, Jabatan $\left(\mathrm{X}_{4}\right)$ secara bersama-sama mempunyai pengaruh terhadap variabel dependen yaitu Kualitas Laporan Keuangan Pemerintah Kabupaten Minahasa Selatan.

\section{Pengujian Hipotesis Secara Parsial (Uji t)}

(X1) Nilai signifikansi sebesar 0,870 > tingkat signifikansi 0,05. Maka Ho diterima dan Ha ditolak, sehingga tingkat pendidikan tidak secara signifikan berpengaruh terhadap kualitas laporan keuangan pemerintah daerah.

(X2) Nilai signifikansi sebesar 0,563 > tingkat signifikansi 0,05. Maka Ho diterima dan Ha ditolak, sehingga masa kerja tidak secara signifikan berpengaruh terhadap kualitas laporan keuangan pemerintah daerah.

(X3) Nilai signifikansi sebesar 0,000 < tingkat signifikansi 0,05. Maka Ha diterima dan Ho ditolak, sehingga pelatihan secara signifikan berpengaruh terhadap kualitas laporan keuangan pemerintah daerah.

(X4) Nilai signifikansi sebesar 0,004 < tingkat signifikansi 0,05. Maka Ha diterima dan Ho ditolak, sehingga jabatan secara signifikan berpengaruh terhadap kualitas laporan keuangan pemerintah daerah.

\section{Uji Koefisien Korelasi (R) dan Koefisien Determinasi (R2)}

Nilai koefisien korelasi (R) sebesar 0,633 menunjukkan bahwa hubungan antara variabel independen dengan variabel dependen merupakan hubungan yang kuat sedangkan nilai $\mathrm{R}^{2}$ adalah 0,401 yang artinya kualitas laporan keuangan sebesar 40,1\% dipengaruhi oleh tingkat pendidikan, masa kerja, pelatihan dan jabatan; sedangkan sisanya 59,9\% dipengaruhi oleh faktor lain di luar penelitian ini.

\section{Pembahasan}

1. Pengaruh Tingkat Pendidikan terhadap Kualitas Laporan Keuangan Pemerintah Daerah

Berdasarkan hasil uji t yang dilakukan untuk melihat pengaruh tingkat pendidikan terhadap kualitas laporan keuangan pemerintah daerah diketahui bahwa tingkat pendidikan mempunyai tingkat signifikansi 0.870 yang berarti nilai ini lebih besar dari 0.05 , berdasarkan hal tersebut disimpulkan bahwa tingkat pendidikan tidak berpengaruh signifikan terhadap kualitas laporan keuangan pemerintah daerah.

Hal ini disebabkan karena tidak semua pegawai yang memiliki tingkat pendidikan yang tinggi paham dan bisa menyelesaikan permasalahan dalam laporan keuangan daerah. Ini dikarenakan kesalahan dalam penempatan pegawai, dimana masih banyak pegawai disetiap SKPD yang ditempatkan tidak sesuai dengan bidang keahliannya. Dan kurangnya pegawai yang berlatar belakang disiplin ilmu akuntansi yang ada. Pegawai yang memiliki disiplin ilmu akuntansi adalah orang yang pandai dan mengerti benar tentang akuntansi. Seseorang dikatakan paham terhadap akuntansi apabila orang tersebut mengerti dan pandai bagaimana proses akuntansi itu dilakukan sampai menjadi suatu laporan keuangan dengan berpedoman pada prinsip dan standar penyusunan laporan keuangan yang ditetapkan dalam peraturan perundang-undangan. Dari segi kualifikasi, banyak SKPD yang bendahara dan kepala sub bagian keuangan yang tidak berlatar belakang akuntansi. Ini dikarenakan faktor kedekatan dengan kepala SKPD, karena bendahara ditunjuk 
langsung oleh kepala SKPD akibatnya proses penyusunan laporan keuangan menjadi terhambat karena minimnya pemahaman pegawai dalam pengelolaan dan penatausahaan keuangan terhadap penyusunan laporan keuangan pemerintah daerah.

Hasil penelitian ini tidak sesuai dengan penelitian yang dilakukan oleh Muzahid (2014), penelitian tersebut menyebutkan bahwa tingkat pendidikan berpengaruh signifikan terhadap kualitas laporan keuangan daerah. Hasil penelitian ini juga tidak sesuai dengan penelitian yang dilakukan oleh Cahyadi (2009), penelitian tersebut menyebutkan bahwa tingkat pendidikan berpengaruh positif terhadap pemahaman atas laporan keuangan daerah.

Penelitian ini sejalan dengan penelitian yang dilakukan oleh Eriva (2013), penelitian tersebut menyebutkan bahwa variabel tingkat pendidikan tidak berpengaruh signifikan terhadap pemahaman laporan keuangan daerah.

\section{Pengaruh Masa Kerja terhadap Kualitas Laporan Keuangan Pemerintah Daerah}

Berdasarkan hasil uji t yang dilakukan untuk melihat pengaruh masa kerja terhadap kualitas laporan keuangan pemerintah daerah diketahui bahwa masa kerja $\left(\mathrm{X}_{2}\right)$ mempunyai tingkat signifikansi 0.563 yang berarti nilai ini lebih besar dari 0.05 , berdasarkan hal tersebut disimpulkan bahwa secara parsial masa kerja tidak berpengaruh signifikan terhadap kualitas laporan keuangan pemerintah daerah.

Hal tersebut merupakan gambaran bahwa tidak selamanya pegawai yang telah lama bekerja lebih menguasai laporan keuangan daerah. Hal ini dapat diakibatkan oleh tingkat kejenuhan pegawai tersebut. Pekerjaan berulang-ulang yang dilakukan secara terus-menerus membuat pegawai menjadi jenuh. Menurut Maslach dan Leiter (1997) dikutip oleh Alinuari (2012), faktor internal terjadinya job burnout (kejenuhan kerja) antara lain umur, jenis kelamin, masa kerja. Hasil penelitian Alinuari (2012) menunjukkan hubungan masa kerja terhadap kejenuhan adalah semakin lama masa kerja seorang pegawai maka kejenuhan kerja semakin meningkat. Pegawai yang mengalami kejenuhan kerja akan mengakibatkan kinerja (job performance) yang menurun sehingga output kerja mereka dapat menurun pula (Gorji, 2011).

Hasil penelitian ini tidak sejalan dengan penelitian yang dilakukan oleh Muzahid (2014), penelitian tersebut menyebutkan bahwa variabel masa kerja berpengaruh signifikan terhadap kualitas laporan keuangan daerah. Hasil penelitian ini juga tidak sejalan dengan penelitian yang dilakukan oleh Cahyadi (2009), penelitian tersebut menyebutkan bahwa masa kerja berpengaruh positif dan signifikan terhadap pemahaman atas laporan keuangan daerah.

Hasil penelitian ini sejalan dengan penelitian yang dilakukan oleh Eriva (2013), penelitian tersebut menyebutkan bahwa masa kerja tidak berpengaruh signifikan terhadap pemahaman laporan keuangan daerah.

\section{Pengaruh Pelatihan terhadap Kualitas Laporan Keuangan Pemerintah Daerah}

Berdasarkan hasil uji $t$ yang dilakukan untuk melihat pengaruh pelatihan terhadap kualitas laporan keuangan pemerintah daerah diketahui bahwa pelatihan $\left(\mathrm{X}_{3}\right)$ mempunyai tingkat signifikansi 0.00 yang berarti nilai ini lebih kecil dari 0.05 , berdasarkan hal tersebut disimpulkan bahwa pelatihan berpengaruh positif dan signifikan terhadap kualitas laporan keuangan pemerintah daerah.

Hal ini menunjukkan bahwa semakin banyak pelatihan yang diikuti pegawai sesuai dengan bidang kerjanya maka akan semakin terampil dan berkualitas pegawai tersebut. Manfaat mengikuti pelatihan adalah agar pegawai terampil, berkualitas dan kompeten dalam bidang pekerjaannya. Pelatihan yang diikuti oleh pegawai terutama pelatihan pada bidang keuangan membuat pegawai paham bagaimana menyusun laporan keuangan dengan baik dan benar sesuai dengan standar dan peraturan perundangan yang berlaku. Semakin sering pegawai mengikuti pelatihan pengelolaan keuangan daerah maka semakin baik laporan keuangan yang dihasilkan.

Hasil penelitian untuk variabel ini sesuai dengan penelitian yang dilakukan oleh Muzahid (2014), penelitian tersebut menyebutkan bahwa variabel pelatihan berpengaruh signifikan terhadap kualitas laporan keuangan daerah. 
Hasil penelitian untuk variabel ini sesuai dengan penelitian yang dilakukan oleh Eriva (2013), penelitian tersebut menyebutkan bahwa variabel pelatihan berpengaruh signifikan terhadap pemahaman laporan keuangan daerah.

4. Pengaruh Jabatan terhadap Kualitas Laporan Keuangan Pemerintah Daerah

Berdasarkan hasil uji t yang dilakukan untuk melihat pengaruh jabatan terhadap kualitas laporan keuangan pemerintah daerah diketahui bahwa jabatan $\left(\mathrm{X}_{4}\right)$ mempunyai tingkat signifikansi 0.04 yang berarti nilai ini lebih kecil dari 0.05 , berdasarkan hal tersebut disimpulkan bahwa variabel jabatan berpengaruh terhadap kualitas laporan keuangan pemerintah daerah.

Hal ini dikarenakan tugas pokok dan fungsi jabatan dijalankan dengan baik. Tanggung jawab sebagai pembuat laporan keuangan benar-benar dipahami tidak hanya mengesahkan hasilnya saja, namun ikut terlibat dalam pembuatan laporan keuangan.

Hasil penelitian untuk variabel ini tidak sesuai dengan penelitian yang dilakukan oleh Eriva (2013), penelitian tersebut menyebutkan bahwa variabel jabatan tidak berpengaruh signifikan terhadap pemahaman laporan keuangan daerah.

\subsection{Kesimpulan}

\section{KESIMPULAN DAN SARAN}

Dari hasil dan analisis statistik dalam penelitian ini, maka diambil kesimpulan antara lain sebagai berikut.

1. Hasil studi menunjukkan tingkat pendidikan $\left(\mathrm{X}_{1}\right)$ secara parsial tidak berpengaruh terhadap kualitas laporan keuangan pemerintah (Y) Kabupaten Minahasa Selatan, dalam hal ini persepsi responden menunjukkan bahwa disebabkan karena tidak semua pegawai yang memiliki tingkat pendidikan yang tinggi paham dan bisa menyelesaikan permasalahan dalam laporan keuangan daerah. Ini dikarenakan kesalahan dalam penempatan pegawai, dimana masih banyak pegawai disetiap SKPD yang ditempatkan tidak sesuai dengan bidang keahliannya.

2. Untuk masa kerja $\left(\mathrm{X}_{2}\right)$ secara parsial tidak berpengaruh terhadap kualitas laporan keuangan pemerintah (Y) Kabupaten Minahasa Selatan, merupakan gambaran bahwa tidak selamanya pegawai yang telah lama bekerja lebih menguasai laporan keuangan daerah dikarenakan tingkat kejenuhan pegawai tersebut.

3. Hasil pengujian uji parsial atau uji t pelatihan $\left(\mathrm{X}_{3}\right)$ berpengaruh terhadap kualitas laporan keuangan pemerintah (Y) Kabupaten Minahasa Selatan, hal ini menunjukkan bahwa semakin banyak pelatihan yang diikuti pegawai sesuai dengan bidang kerjanya maka akan semakin terampil dan berkualitas pegawai tersebut.

4. Untuk jabatan $\left(\mathrm{X}_{4}\right)$ secara parsial berpengaruh terhadap kualitas laporan keuangan pemerintah (Y) Kabupaten Minahasa Selatan, hal ini dikarenakan tugas pokok dan fungsi jabatan dijalankan dengan baik.

\subsection{Saran}

Dari hasil penelitian yang ada, maka saran yang dapat diberikan adalah sebagai berikut :

1. Penelitian berikutnya harus mempertimbangkan karakteristik atau variabel lain yang mempengaruhi kualitas laporan keuangan pemerintah daerah misalnya komitmen, gaya kepemimpinan.

2. Memberikan tambahan informasi untuk penelitian selanjutnya sehingga dapat membantu pengembangan Ilmu Akuntansi khususnya Akuntansi sektor publik.

3. Bagi Pemerintah Kabupaten Minahasa Selatan, diberikannya pelatihan dan pendidikan bagi pegawai yang terlibat dalam pengelolaan keuangan daerah agar lebih memahami proses akuntansi dan pembukuan, yang merupakan dasar dalam melaksanakan pelaporan keuangan yang baik sebagai bagian dalam pengelolaan keuangan daerah. 


\section{DAFTAR PUSTAKA}

Alinuari, Janti. 2012. Hubungan Kerja Monotoni dengan Kejenuhan Kerja pada Pekerja Bagian Spinning PT. Tyfountex Indonesia Sukoharjo. Universitas Sebelas Maret. Surakarta

Alma, Buchari. 2008. Metoda dan Teknik Menyusun Tesis. Alfabeta Bandung.

Almanidar, E. 2010.Pemahaman Aparatur Terhadap Proses Penyusunan Laporan Keuangan Entitas Pada Pemerintah Daerah Kabupaten Pidie. Tesis. Banda Aceh : Program Pascasarjana Universitas Syiah Kuala.

Arfan \& Faisal. 2009. Pengaruh Masa Kerja, Jabatan dan Jenjang Pendidikan Terhadap tingkat Pemahaman Aparatur Pemerintah Tentang Prinsip-prinsip Good Governance di Pemerintah Kota Banda Aceh. Jurnal Telaah \& Riset Akuntansi. Vol. 2:1-14.

Badan Pemeriksa Keuangan Republik Indonesia. 2015. Ikhtisar Hasil Pemeriksaan Tahun 2014.

Basrowi \& Suwandi. 2010. Memahami Penelitian Kualitatif. Jakarta : Rineka Cipta.

Cahyadi, Dwi. 2009. Pengaruh Tingkat Pendidikan, Masa Kerja, Pelatihan dan Posisi di Pemerintahan Terhadap Pemahaman Laporan Keuangan Daerah (Studi Empiris Pada Eksekutif Dan Legislatif di Lembaga Pemerintahan Kabupaten Banjarnegara). Tesis. Universitas Diponegoro. Semarang.

Eriva, Cut Yunina., Islahuddin, dan Darwanis. 2013. Pengaruh Tingkat Pendidikan, Pelatihan, Masa Kerja dan Jabatan Terhadap Pemahaman Laporan KeuanganDaerah (Studi Pada Pemerintah Aceh), Jurnal Akuntansi. Pasca Sarjana Universitas Syiah Kuala.

Fuller, Francis. 1969. Concern of Teacher A Development Conceptualization. Journal of America Research Vol. VI No. 2.

Ghozali, Imam. 2006. Aplikasi Analisis Multivariate Dengan Program SPSS. Badan Penerbit Universitas Diponegoro. Semarang.

Gorji, Muhammadbagher. 2011. The Effect of Job Burnout Dimension on Employees Performance.International Journal of Social Science and Humanity, Vol. 1, No. 4.

Hariandja, Marihot Tua Efendi. 2007. Manajemen Sumber Daya Manusia : Pengadaan, Pengembangan, Pengkompensasian, dan Peningkatan Produktivitas Pegawai. Jakarta : Grasindo.

Hasbulah, 2008.Dasar-dasar Ilmu Pendidikan.Jakarta : PT Raja Grafindo Persada.

Herliansyah, Yudhi dan Meifida Ilyas. 2006. Pengaruh Pengalaman Auditor Terhadap Penggunaan Bukti Tidak Relevan Dalam Auditor Judgement.SNA IX Padang.

Indriantoro, Supomo. 2002. Metodologi Penelitian bisnis untuk Akuntansi dan Manajemen. Edisi Pertama.BPFE. Yogyakarta.

Mahmudi. 2010. Analisis Laporan Keuangan Pemerintah Daerah. Panduan bagi Eksekutif, DPRD dan Masyarakat dalam Pengambilan Keputusan Ekonomi, Sosial dan Politik. Penerbit Sekolah Tinggi Ilmu Manajemen YPKN.

Mustopadidjaja. 2002. Paradigma-paradigma Pembangunan. Lembaga Administrasi Negara.

Muzahid, Mukhlisul, 2014. Pengaruh Tingkat Pendidikan, Kualitas Pelatihan dan Lama Pengalaman Kerja Pegawai Terhadap Kualitas Laporan Keuangan SKPD di Kabupaten Aceh Utara.Jurnal Akuntansi.Volume 9. Nomor 1.1-26

Nasaruddin, F. 2008. Pengaruh Pendidikan, Pelatihan dan Pengalaman Kerja Terhadap Kualitas Penyajian Informasi Akuntansi pada PT. Bank Negara Indonesia Tbk. Jurnal Ichsan Gorontalo Vol. 3: 1411-1420.

Nawawi, Hadari. 1981. Administrasi Pendidikan. Jakarta: Gunung Agung.

Nazier, D. M. 2009.Kesiapan SDM Pemerintah Menuju Tata Kelola Keuangan Negara yang Akuntabel dan Transparan.Seminar Nasional, tanggal 22 juli 2009.

Nitisemito, A. S. 1996. Manajemen Personalia: Manajemen Sumber Daya Manusia. Jakarta: Gholia Indonesia.

Nursari, Dini Pradipta, 2011. Pengaruh Latar Belakang Pendidikan dan Pelatihan Terhadap Pemahaman Laporan Keuangan SKPD Pemerintah Kota Bandar Lampung.Jurnal Akuntansi.Universitas Lampung. 
Pujangkoro, Sugih Arto.2004. Analisis Jabatan (Job Analysis). Jurnal Jurusan Teknik Industri Fakultas Teknik Universitas Sumatera Utara.

Permendagri No. 59 Tahun 2007 tentang Perubahan atas Peraturan Menteri Dalam Negeri No. 13 Tahun 2006 Tentang Pedoman Pengelolaan Keuangan Daerah.

Peraturan Pemerintah No. 71 Tahun 2010 Tentang Standar Akuntansi Pemerintahan.

Risalawati, Fitri. 2014. Pemanfaatan Laporan Posisi Keuangan Oleh Pengguna Dalam Pengambilan

Keputusan (Studi Empiris pada Instansi Pemerintahan di Jawa Tengah).Jurnal Akuntansi. Universitas Diponegoro. Semarang

Sarwono, Jonathan. 2012. Path Analysis dengan SPSS, Penerbit PT Elex Media Komputindo.

Sugiyono. 2009. Metode Penelitian Bisnis. Bandung : Alfabeta

Sukirman, D. 2009. Terbatasnya Kompetensi SDM Salah Satu Penyebab Buruknya Pengelolaan Keuangan daerah.Warta Pengawasan Vol. XVI No. 1.

Sumantri, S. (2000), Pelatihan dan Pengembangan Sumber Daya Manusia,Bandung, Fakultas Psikologi Unpad.

Surachmad, Winarno. 1982. Pengantar Interaksi Belajar Mengajar. Bandung: Tarsito.

Sekaran, Uma. 2006. Research Methods for Business. Fourth Edition. Jakarta: Salemba Empat.

Tulus, Moh. Agus. 1996. Manajemen Sumber Daya Manusia. Jakarta : PT Gramedia Pustaka Utama.

Undang-Undang Republik Indonesia Nomor 20 Tahun 2003 Tentang Sistem Pendidikan Nasional.

Undang-Undang Republik Indonesia Nomor 32 Tahun 2004 Tentang Pemerintahan Daerah.

World Bank. 2007. Pengelolaan Keuangan Publik di Aceh, Mengukur Kinerja Pemerintah Daerah di Aceh. www.worldbank.or.id.

Zetra, A. 2008.Strategi Pengembangan Kapasitas SDM Pemerintah Daerah Dalam Mewujudkan Transparansi dan Akuntabilitas Pengelolaan Keuangan Daerah. Jurnal Akuntansi. Universitas Andalas. 